\title{
Epilogue
}

\begin{abstract}
The analysis of Israel in Jewish education is a lens for reflecting on the relationship between ethnic education and ethical education. It sometimes is the case that through our particularity we find our humanity. Particularistic education might also encompass education for a life of values, character, and benevolence. Such education requires faith in people and their journeys through the texts, history, and events of their own culture and also of other cultures.
\end{abstract}

Keywords Dialogical • Humanitas • Hebrew Humanism • Liberal learning

\section{Homeland and Humanitas}

This book has focused on the place of Israel in contemporary Jewish education. It has proposed a philosophy of Israel education rooted in the personal relationship between contemporary youth and the value of the Land of Israel. This educational vision implies a pedagogy of direct conversations between the young and core voices and texts of the Land of Israel and the contemporary State of Israel. These texts and voices point to the ongoing commitment of the Jewish people to the value of Israel over time, as well as to the diversity of meanings of the value of Israel. This educational approach to Israel education is understood as value education, which

(C) The Author(s) 2016

B. Chazan, A Philosophy of Israel Education, DOI 10.1007/978-3-319-30779-4_4 
means that ultimately it is aimed at the development of personal character. In this epilogue, we reflect on implications of this study beyond the Jewish sphere. The presenting question is "Can an education that focuses on a specific ethnic or affiliative group also be a framework for character education?”

\section{From Ethnic to Ethic}

Our approach to Israel education reflects some core understandings of the concept of education. We regard the individual as the main focus of education. This focus does not negate the importance of social identities in shaping who we are. However, ultimately education is about the personal journey to becoming human. This person-centered approach is particularly significant in our postmodern world of multiple identities and voluntary affiliations; it reflects the long-standing tradition of humanistic education which regards the goal of education to be how to be human or how to live a good life. The process of choosing values is not haphazard or casual; rather, it is a reflective process, which is ignited by the passion to seek and find a meaningful set of values for one's life. Our study of Israel education suggests that the gateway to meeting these values is through the diverse texts and documents of a tradition. We learn about a tradition's values by studying its "personal diary"-the records of what it professes to believe and what it becomes in practice. Indeed, the values of nations and peoples are recorded both in documents and equally in the norms and practices of its daily life. The ultimate confrontation with values is the dialogical confrontation between the individual and these written and lived testimonies.

What are the implications of these emphases for the challenge of transforming ethnic education into ethical education? First, the person, and not the ethnos, is the center of education. Second, such education encourages reflection on values that are posited, rather than on conclusions to be imposed. Third, education's role is to help students learn how to choose and not to abandon them to whim or other-directedness. Fourth, education for values is not a subject to be studied only in the abstract. The measure of the values of a people, a nation, or a culture is both their theoretical suppositions and their implementation in practice. Fifth, the existence of multiple values does not mean that values are ultimately personal, parochial, or arbitrary. Values must stand the test of reason, insight, and 
universalizability. Finally, the quest for values is about the search for ideals that know no national borders and that are applicable for people regardless of their voluntary or involuntary affiliations.

An important teacher of this educational vision is the twentieth-century German-Jewish philosopher Martin Buber. ${ }^{1}$ Buber utilized the phrase "Hebrew Humanism" to refer to a worldview which he believed synthesized the great Hebraic and humanistic traditions in a compelling way. His understanding of the humanistic or humanitas is "the belief that man is not merely a zoological species, but a unique creature" whose lot it is to seek and find the inherently human in his/her self ${ }^{2}$ (Buber 1941). The "Hebrew" part of his phrase refers to the specific ethos of the Jewish people whose source is the Bible, "which divides right from wrong, truth from lies, as unconditionally as the words of the Creator divided light from darkness" (p. 162, op cit.). Hebrew humanism is a synthesis of these two visions, which is both a philosophical concept and an action plan for a Jewish homeland. Buber was a supporter and active participant of that enterprise. At the same time, he was insistent on warning new and old nations of the misguided and egotistical tendency of nation states to forget the person and to deify the state.

\section{Toward a New Ethnic Educational Vision}

We believe that, under the right conditions, particularistic education can be a significant force in education for a life of values, character, and benevolence. Indeed, it is often the case that through our particularity we find our humanity. Such education requires faith in people and their journeys through the texts, history, and events of their own culture and also of other cultures. The journey to the "State of Humanitas" is ongoing, confusing, invigorating, and thought-provoking. It is our mission and calling as educators to serve as guides, mentors, and partners of the young on this journey. Our contemporary world, at times, appears as if "things fall apart; the center cannot hold and mere anarchy is loosed upon the world" (Yeats 1950). Perhaps, we can help our young of diverse affiliations and identities to yet meet together in the State of Humanitas.

\section{BIBLIOGRAPHY}

Yeats, W. B. (1950). The collected poems of W.B. Yeats. London: Macmillan. Print. 


\section{Notes}

1. Martin Buber was born in 1878 in Vienna and died in 1965 in Jerusalem. He was a professor and activist of Jewish communal affairs in Germany until 1938 when he immigrated to Palestine and served as a professor at Hebrew University of Jerusalem. His major works on education include Teaching and the Deed, On National Education, "Education" and Education of Character. Essays related to Hebrew humanism include "Hebrew Humanism", "Nationalism", "Biblical humanism" and "Zionism and Nationalism".

2. Buber's term "humanitas" is related to the term "liberal learning" used by British philosopher Michael Oakeshott to refer to the search for the core values that make each of us human. Oakeshott saw learning as an ongoing adventure and journey in exploring, observing, and choosing values of worth that shape our lives and human society. The travelers in this journey engage in conversations with works of art, literature, philosophy, and architecture, which help them over time to understand what it means to be human. This education is denoted as liberal.

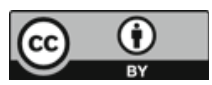

This chapter is distributed under the terms of the Creative Commons Attribution 4.0 International License (http://creativecommons.org/ licenses / by $/ 4.0 /$ ), which permits use, duplication, adaptation, distribution and reproduction in any medium or format, as long as you give appropriate credit to the original author(s) and the source, provide a link to the Creative Commons license and indicate if changes were made.

The images or other third party material in this chapter are included in the work's Creative Commons license, unless indicated otherwise in the credit line; if such material is not included in the work's Creative Commons license and the respective action is not permitted by statutory regulation, users will need to obtain permission from the license holder to duplicate, adapt or reproduce the material. 